\title{
Seepage Velocity of Dibdibba Formation in Karbala, Iraq
}

\section{Qais Al-Madhlom ${ }^{1,2}$, Nadhir Al-Ansari', Hussain M. Hussain ${ }^{3}$, Jenny Lindblom ${ }^{1}$, Twana Abdullah', Bashar Abid Hamza², Sven Knutsson ${ }^{4}$}

${ }^{1}$ Lulea University of Technology, Lulea, Sweden

${ }^{2}$ University of Babylon, Coolege of Engineering, Babylon, Iraq

${ }^{3}$ Department of Geology, College of Science, Kufa University, Kufa, Iraq

${ }^{4}$ Department of Civil, Environmental and Natural Resources Engineering, Lulea, Sweden

Email: qais.al-madhlom@ltu.se, nadhir.alansari@ltu.se, Jenny.Lindblom@ltu.se,twana.abdullah@ltu.se,

basharabid74@yahoo.com,hussainm.alshimmary@uokufa.edu.iq

How to cite this paper: Al-Madhlom, Q. AL-Ansari, N., Hussain, H.M., Lindblom, J., Abdullah, T., Hamza, B.A. and Knutsson, S. (2017) Seepage Velocity of Dibdibba Formation in Karbala, Iraq. Engineering, 9, 279-290.

https://doi.org/10.4236/eng.2017.93015

Received: March 1, 2017

Accepted: March 28, 2017

Published: March 31, 2017

Copyright (C) 2017 by authors and Scientific Research Publishing Inc. This work is licensed under the Creative Commons Attribution International License (CC BY 4.0).

http://creativecommons.org/licenses/by/4.0/

\begin{abstract}
Iraq highly depends on its surface water resources. Now it is facing water shortage problems. For these reasons, the utilization of groundwater will be increasing with time. Karbala Governorate is located in the central part of Iraq. It covers an area of $5034 \mathrm{~km}^{2}$ and the population exceeds one million. It is characterized by an arid or semiarid environment. Karbala Governorate lack surface water resource and consequently, groundwater is the only available resource. The main groundwater aquifer within the area is Dibdibba formation. It is composed of poorly sorted sand and sand stone with gravel. In this research hydrological and hydrogeological information were used to find out the magnitude and the direction of groundwater seepage velocity. The results indicate that groundwater flow toward the flood plain to the east of the study region. The seepage velocity ranges from 0 to $0.18 \mathrm{~m} / \mathrm{d}$, with a general increase when moving from the west to the east.
\end{abstract}

\section{Keywords}

Dibbdiba Formation, Seepage Velocity, Karbala, Iraq

\section{Introduction}

Groundwater is one of the most important sources of water in the world, since it represents $30 \%$ of the fresh water that consists (fresh water) in about $2.5 \%$ of the whole water on the earth [1] [2]. This importance increases enormously especially for those countries that don't have surface water. Iraq heavily relies (95\%) on its surface water resources [3] [4]. It was considered as one of the richest countries in 
its water resources where the allocation per capita was $6029 \mathrm{~m}^{3}$ in 1995 and dropped to $2100 \mathrm{~m}^{3}$ in 2015 [3] [4] [5] [6] [7]. Recently, Iraq is suffering from water shortage problems due to the effect of climate change and building of dams upstream the Tigris and Euphrates Rivers and their tributaries [3] [7] [8]. With this shortage in surface water in Iraq, it becomes very important to look for another resource of fresh water, which can fulfill the requirements of both the municipal and agricultural practices. The most promising resource of fresh water in middle of Iraq is groundwater. This is due to many reasons among them are its quality and occurrence near the ground surface.

Karbala Governorate is one of the most important Iraq middle cities from its religious point of view. It covers an area of $5034 \mathrm{~km}^{2}$ and has a population that exceeds one million capita [9]. In this research the seepage velocity (magnitude and direction), it was evaluated for an area within Karbala Governorate, due to the importance of these variables in calculating many properties like the contaminants transporting velocity inside the aquifer, the well discharge rate, permeability of the aquifer, hydraulic conductivity, Darcy velocity and other geohydrology properties.

\section{Study Area}

The study area is a part of Karbala Governorate and it is located between Karbala and Najaf Governorates (in the middle of Iraq), between 412,000 - 432,000 UTM longitude and 3,574,000 - 3,594,000 UTM latitude. It covers an area of 400 $\mathrm{km}^{2}$. It is surrounded by Khan Al-Nukhaylah from the north, Khan Al-Hammad from the south, oil pipe from the west, and Euphrates River from the east (Figure 1). The study area is a part from Dibdibba Basin where Dibdibba formation is exposed. Dibdibba Basin $\left(2485 \mathrm{~km}^{2}\right)$ covers a part of Karbala Najaf region and can be represented by a triangle plateau surrounded by Tar-Al-Sayad from the west, Tar-AL-Najaf from the south, and by the flood plain from the east. This

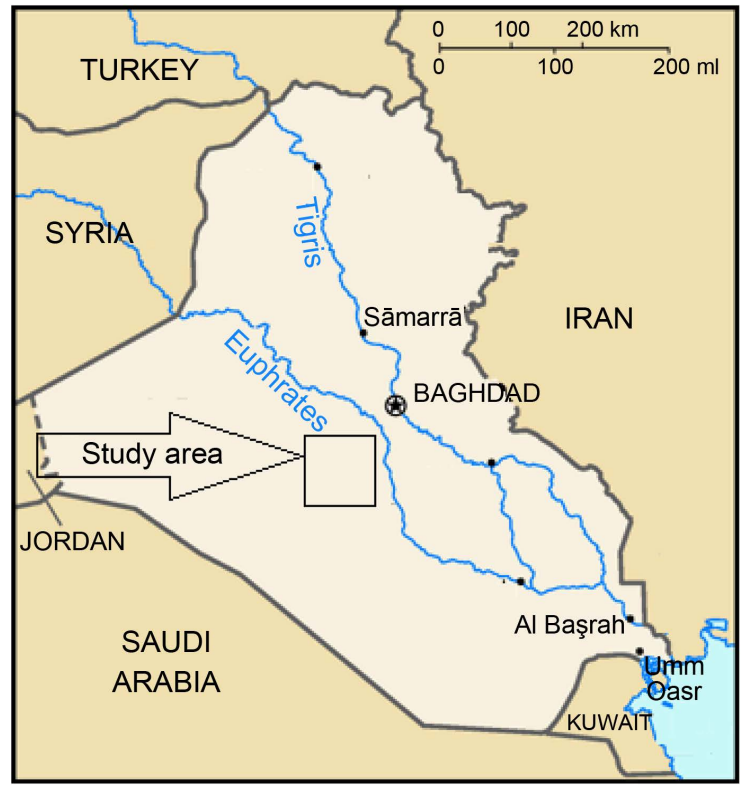

Figure 1. Location of the study area. 
basin has a dip that ranges from $0.5 \%$ to $0.1 \%$ from the west to the east (Figure 2) [10].

Dibdibba formation is composed of poorly sorted sand, sand stone with gravel. The mineral composition of Dibdibba formation consists of $84.2 \%$ Quartz, 8.5\% rock fragment, and 7.3\% feldspar [11]. This (Pliocene-Pleistocene) formation is underlain by Injana (Upper Miocene) formation, which is in turn underlain by Nfayil (Middle Miocene) formation, then Euphrates (Early Miocene) formation as shown in Figure 2 [12]. Injana formation in the study area represents a confining or semi-confining layer for Dibdibba formation [10]. This forces the ground water to flow horizontally in the dip direction of Dibdibba formation through its thickness which ranges, in general, from 1 meter or less to about 18 meters [11]. Within the studied area however, it ranges from $25 \mathrm{~m}$ to $70 \mathrm{~m} \mathrm{[10].}$

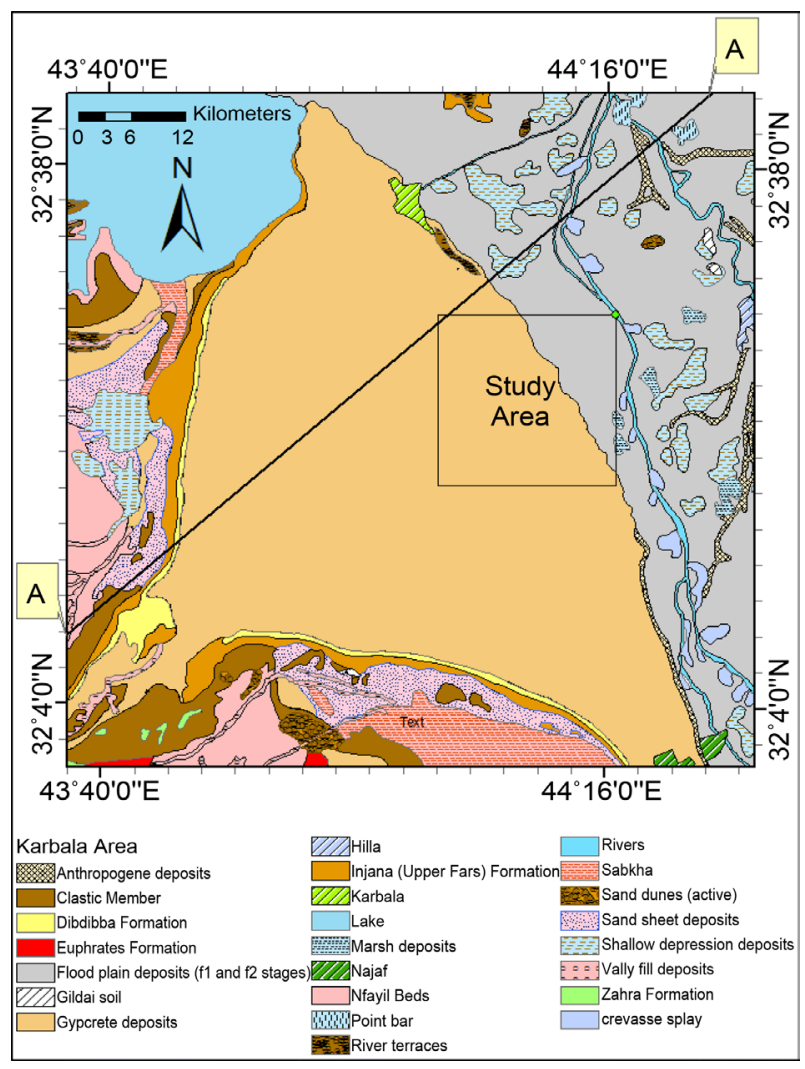

(a)

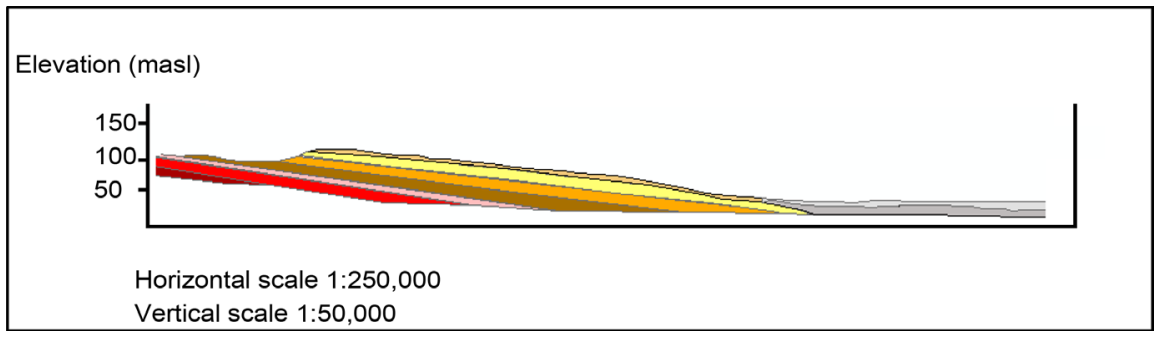

(b)

Figure 2. (a) Boundaries of Dibdibba Basin; (b) cross section inside Dibdibba formation [13]. 


\section{Review of Literature}

Number of researchers realized the importance of the Dibdibba basin due to: Its arid or semi-arid climate, which leads to low rains and limited rain recharge, and low fluctuation in groundwater table. Beside that there are many reasons incentivize researchers to study this area, like:

1) It is located within a major city (Karbala).

2) Absence of surface water resources in the area where it is far from Euphrates and Tigris rivers.

3) Its arid or semi-arid area, having low rain, limited recharge, and low fluctuation in groundwater table.

4) Underlain by Injana formation and having a free water table, making it unconfined basin aquifer type, which facilitates the measuring process.

5) Shallow ground water, which produces an effective and quick recharge process.

6) Available hydrological and geo-hydrological information of the area.

7) Presence the natural boundaries around Dibdibba Basin, and having a dip from the west to east toward the flood plain lead to more accurate estimation process.

8) The increasing usage of the groundwater within the area.

Al-Ani [10] estimated the groundwater recharge of Dibdibba aquifer by using four techniques (groundwater fluctuation, water budget, numerical method/ Mod Flow/simulation model, and tracers). He found out that the tracer technique gave the closest results to the water exploitation in that area. Al-Mussawi [14] found the groundwater contour maps for the study area using Kriging and Inverse Distance Weighted (IDW) methods, and demonstrated the groundwater table decreasing in the direction from the west to the east. Ibrahim [15] studied the hydrochemistry of the area, and found high concentration of $\mathrm{Ca}^{2+}$ and $\mathrm{SO}_{4}{ }^{2-}$ in addition to heavy metal $\mathrm{Zn}$ and Al. Al-Saadi [16] classified the groundwater of Karbala Governorate according to WHO and Iraqi standards, US Salinity hazard laboratory classification [17], Wilcox specification [18], and permeability index (PI by Doneen [19]) classifications. According to those classification he found that the groundwater in some places is suitable and in others not suitable for drinking and irrigation purposes. Ramadhan [20] evaluated the groundwater recharge in the study area using four methods: fluctuating water table, water balance of the basin, numerical modelling, and balance of chloride ion mass in unsaturated zone. He found that the values from the last method (chloride ion mass balance) are the most accurate values comparatively to the volume of water from the renewed inventories. Khalaf [21] located the best places to drill irrigation wells in the study area according to the topography of the region, sodium ratio, total dissolved salt, and groundwater elevation. In addition, he stated that there are two aquifers in the area: Dibdibba and Dammam. Thabit [22] generated 3-D image that simulate the resistivity for an area of $30 \mathrm{~m} * 30 \mathrm{~m}$, then he used this image to demonstrate the seepage velocity-depth relation. He noticed that the maximum seepage velocity occurred in the depth ranged from 3 to $6 \mathrm{~m}$ 
below the ground surface, and the seepage velocity direction is from south west to north east of that area.

Despite the number of published papers, no article was found to evaluate the magnitude of seepage velocity of the study area $(20 \mathrm{~km} * 20 \mathrm{~km})$ shown in Figure 1 . Therefore this article was performed to estimate this important geohydrological property.

\section{Methodology}

Seepage velocity refers to the velocity of the flowing liquid through the pores of the porous media. It can be calculated by dividing Darcy's velocity by the effective porosity, as follow [23]:

$$
v=\frac{q}{n}
$$

where:

$v$. The seepage velocity $(\mathrm{m} / \mathrm{d})$,

$q$ : Darcy's velocity (m/d),

$n$ : The effective porosity.

Darcy's velocity can be found by the following equation:

$$
q=-K \nabla H
$$

where:

$K$ : The hydraulic conductivity $(\mathrm{m} / \mathrm{d})$,

$\nabla H$ : Head gradient (the change in the hydraulic head per unit length in the direction of the flow in an isotopic aquifer).

Since, hydraulic conductivity is equal to the transmissivity ( $\mathrm{T}$ ) divided by the effective thickness of the aquifer (b), therefore, Equation (1) can be rewritten as follow:

$$
v=-(T \nabla H) /(\mathrm{bn})
$$

To generate seepage velocity maps (magnitude and direction maps) by GIS ArcMap software, four maps should be found first, they are:

1) Groundwater elevation head map.

2) Aquifer effective porosity map.

3) Aquifer saturated thickness map.

4) Aquifer transmissivity map.

All these maps should be in a raster type (with floating points) and have the same extent and cell size; otherwise the calculation process cannot be executed. Also all the dimensional parameters should be homogenous (i.e. the same unit for length and time). Ground water elevation (in the equations) is taken from a certain datum, which is usually the sea level.

The resulting maps after performing the commands (Darcy Velocity) in GIS/ArcMap are two maps: the first is seepage velocity magnitude map and the other is seepage velocity direction map. The direction map can be explained in an arrows map, while the magnitude map is explained as a raster map with floating values. 
The process for finding Darcy's maps includes the projection of the wells on the UTM coordinate system map either by interpolation using Kriging method which is more accurate or IDW which is less accurate. In this work Kriging method was used. Maps representing the four parameters (groundwater head elevation, effective porosity, saturated thickness, and transmissivity) were constructed. The same cell size for all maps was used. The input of these four maps was used in the command interference concerning Darcy velocity, to get the seepage velocity maps (magnitude and direction).

\section{Results and Discussion}

After collecting the necessary information to establish the four primary maps that are required for generate Darcy maps, GIS/ArcMap software was used to generate these maps using Kriging command (Figures 3-6). Figure 3, shows the groundwater head elevation above sea level in meter. From the figure it can be noticed that the water table dips toward the east. According to that, the ground water is flowing from the west to the east.

The effective porosity of aquifer in the study area is shown in Figure 4. Since there are no measured values for the porosity within this area, Todd [23], and (GIS/ArcMap/Help) porosity ranges for different porous media were used. It had assumed that the average value for the porosity was $37 \%$. Figure 5 shows the

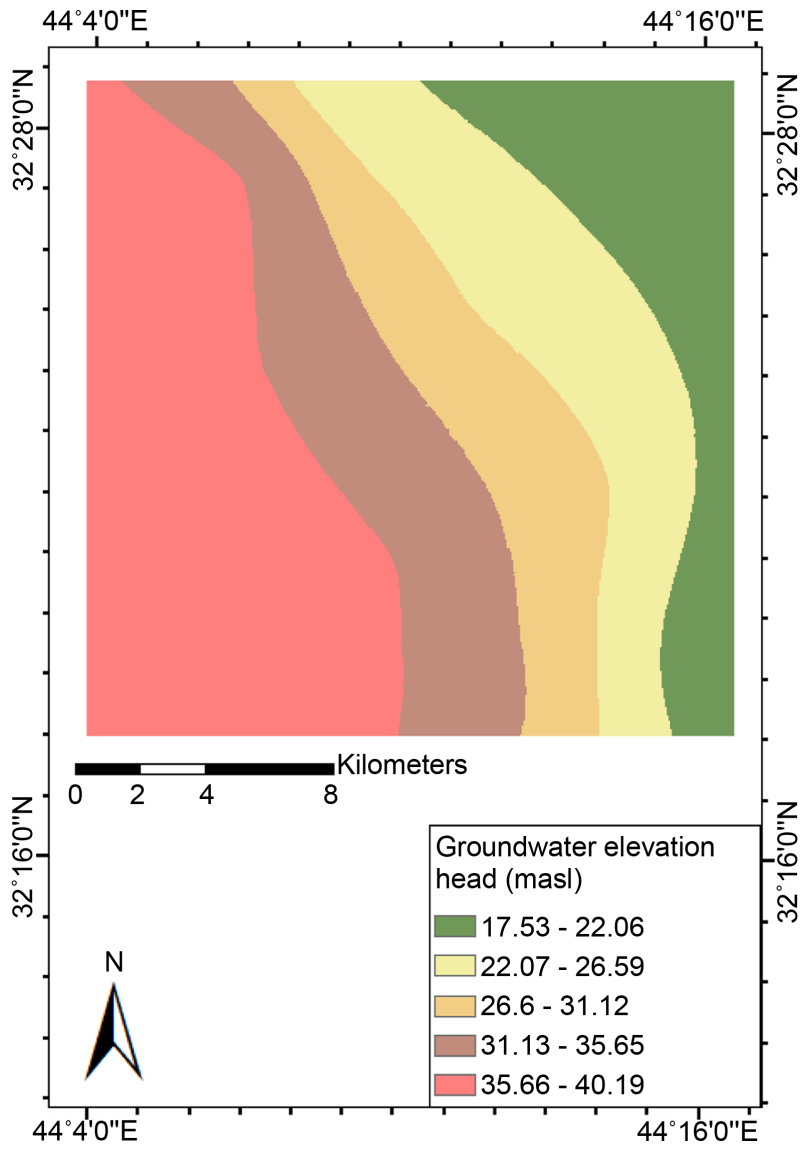

Figure 3. Groundwater head elevation (m.a.s.l). 


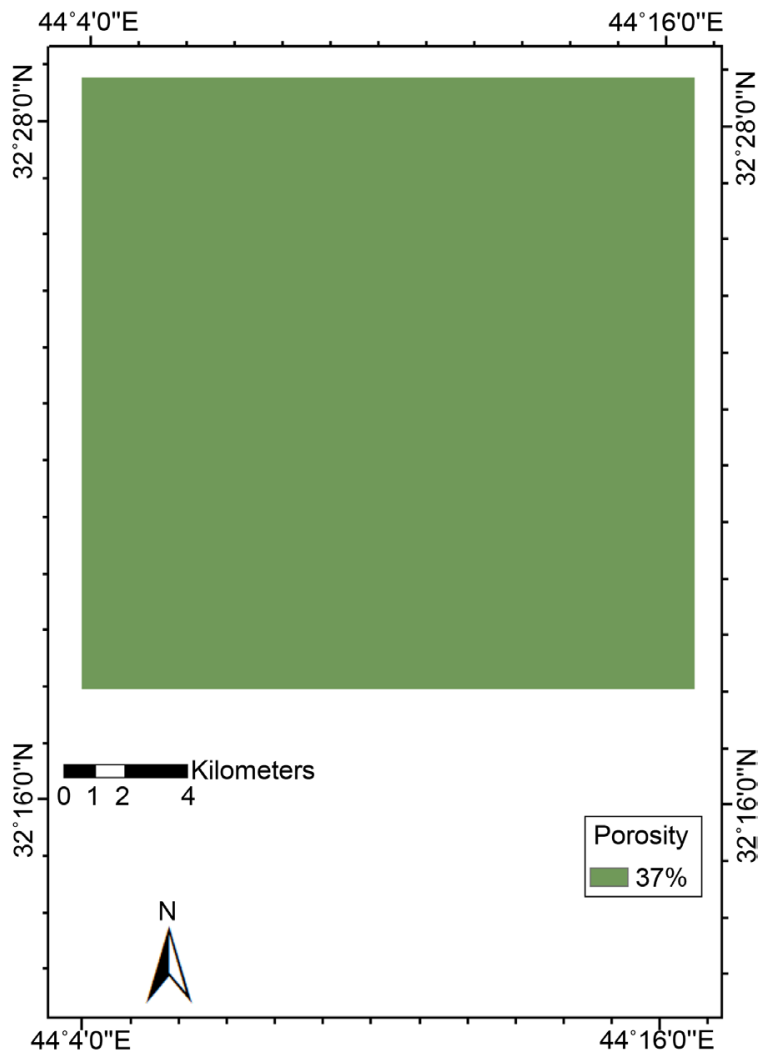

Figure 4. Effective porosity.

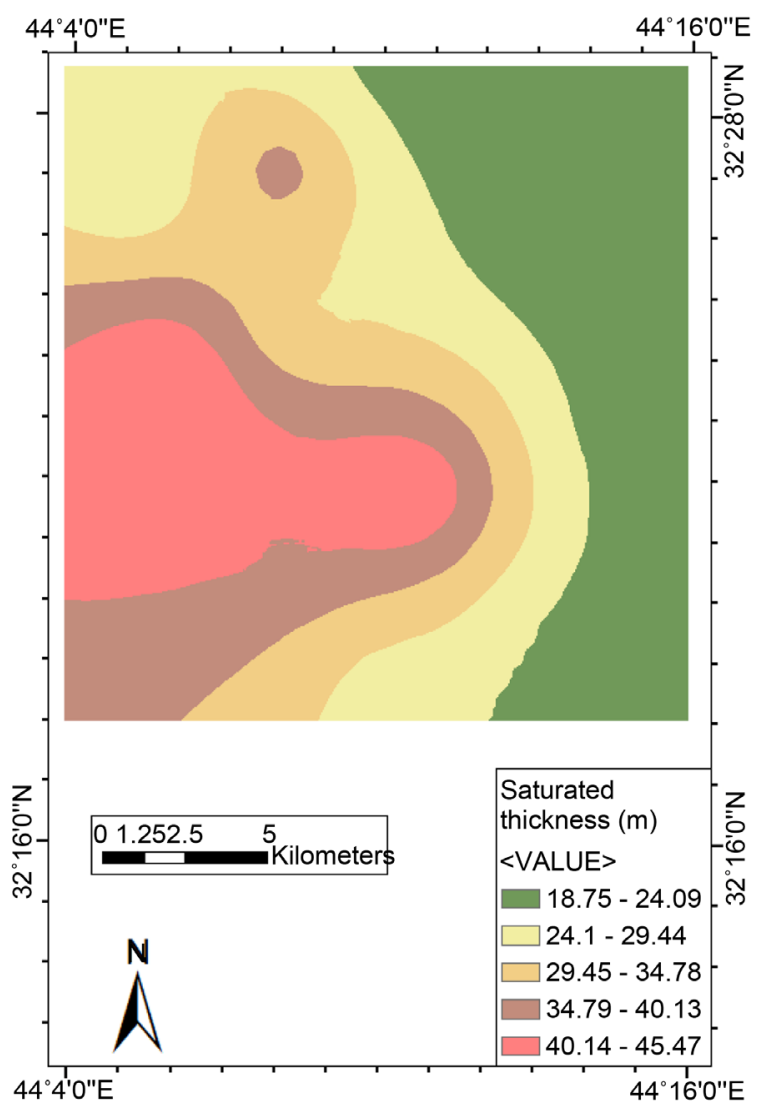

Figure 5. Saturated thickness (m) for the study area. 


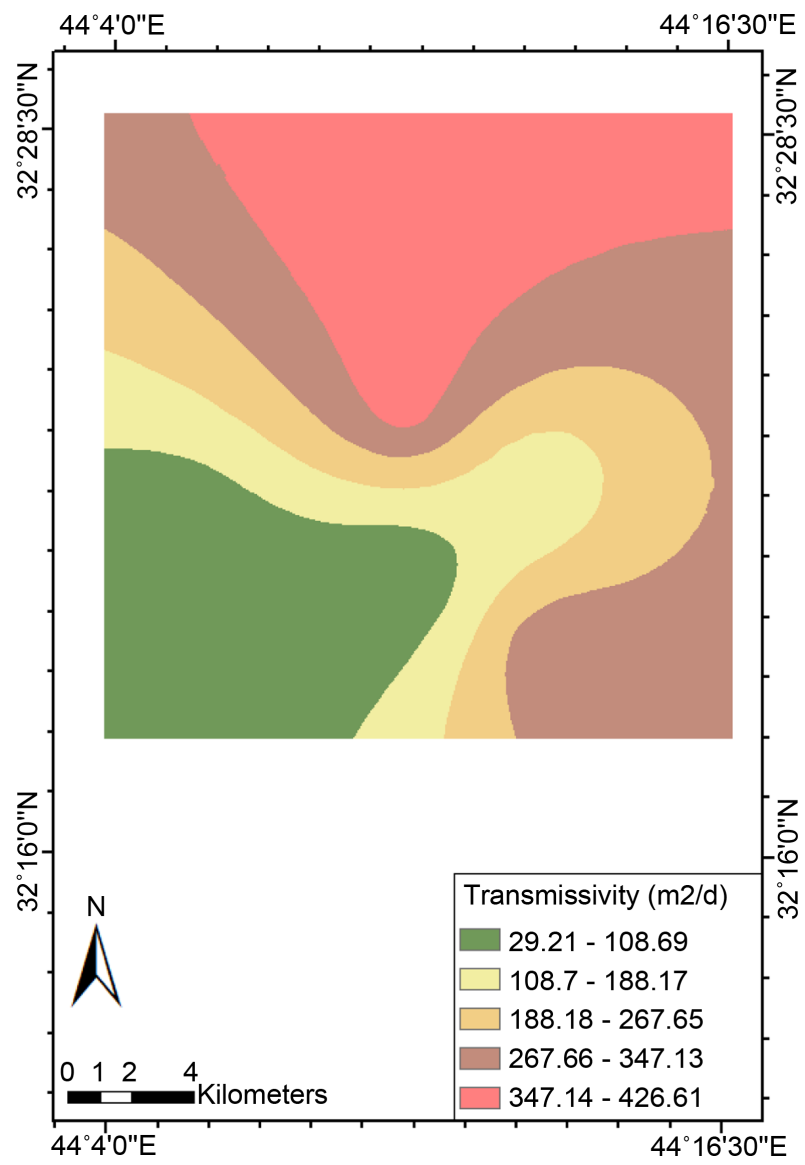

Figure 6. Transmissivity $\left(\mathrm{m}^{2} / \mathrm{d}\right)$.

saturated thickness of Dibdiba formation in the study area. The figure indicates that the saturated thickness of the western region is more than that the eastern region. The saturated thickness dips from $45 \mathrm{~m}$ in the west to $18.75 \mathrm{~m}$ in the east. Figure 6 demonstrates the transmissivity of the study area in $\left(\mathrm{m}^{2} /\right.$ day). It can be conducted that the transmissivity increase in the east and north east direction. And it ranges from $29 \mathrm{~m}^{2} / \mathrm{d}$ to $426 \mathrm{~m}^{2} / \mathrm{d}$.

After producing the four maps (groundwater head elevation, effective porosity, saturated thickness, and transmissivity maps), they were used to generate seepage velocity maps (magnitude and direction maps), through inputting them in the command interface of Darcy Velocity. The resulting maps are shown in Figure 7 and Figure 8. Figure 7 shows that the seepage velocity range is 0 to $0.18(\mathrm{~m} / \mathrm{d})$. Figure 8 reveals the seepage velocity direction. The overall flow direction is from the west to the east. The reasons beyond that are the dip of the Injana upper surface which represents an impervious bed underlying Dibdibba formation and the dip of water table toward the east direction. Figure 9 represent the combination of the seepage velocity direction map and the groundwater head elevation map. In Figure 9 the seepage velocity direction is perpendicular to the groundwater potential line which it is a reasonable result. Figure 10 represent the combination of the seepage velocity maps (magnitude and direction). 


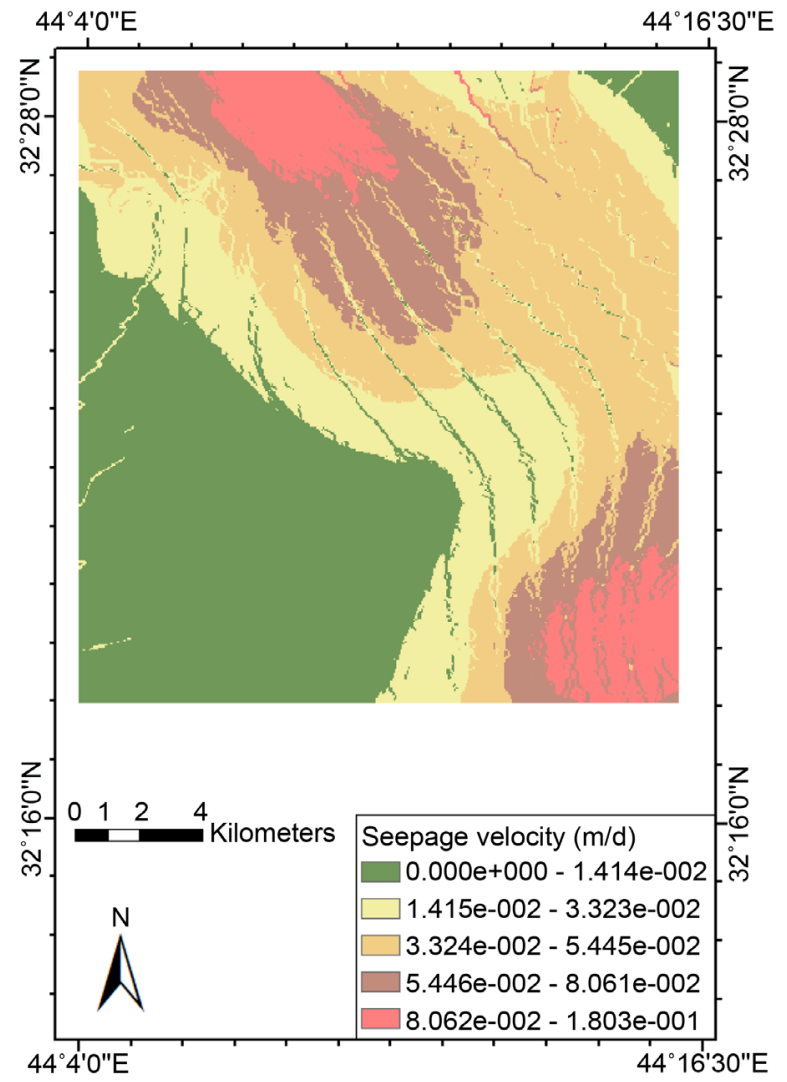

Figure 7. Seepage velocity magnitude.

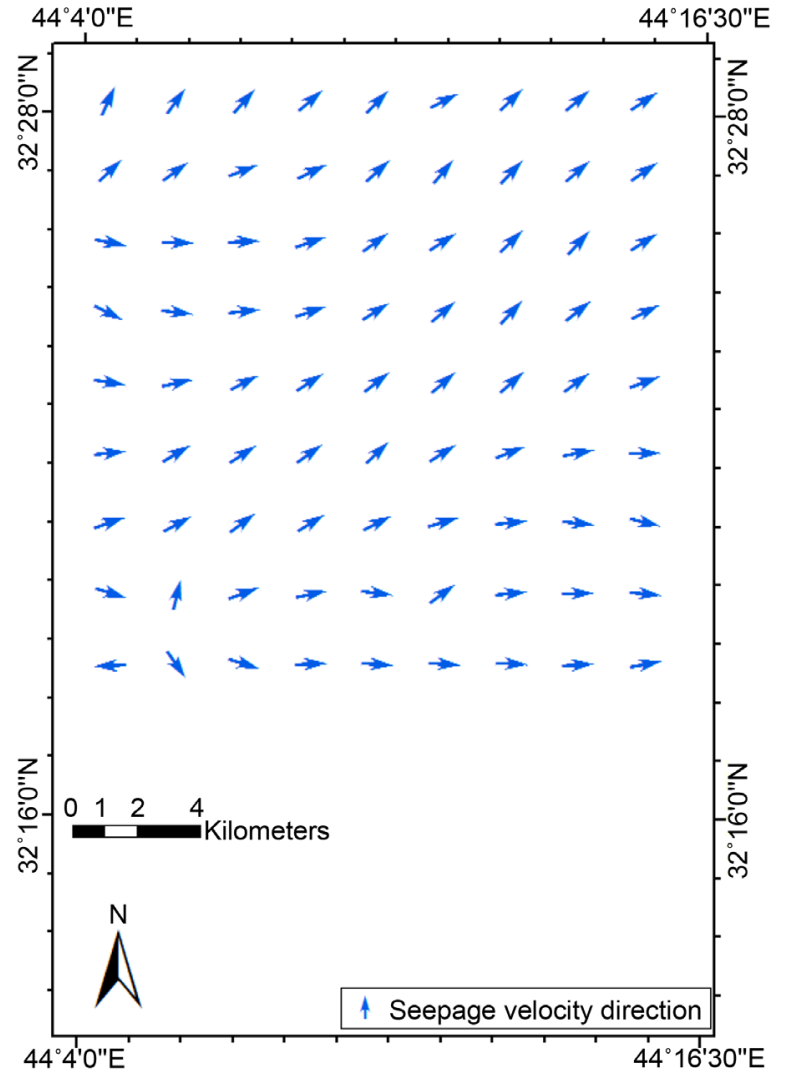

Figure 8. Seepage velocity direction. 


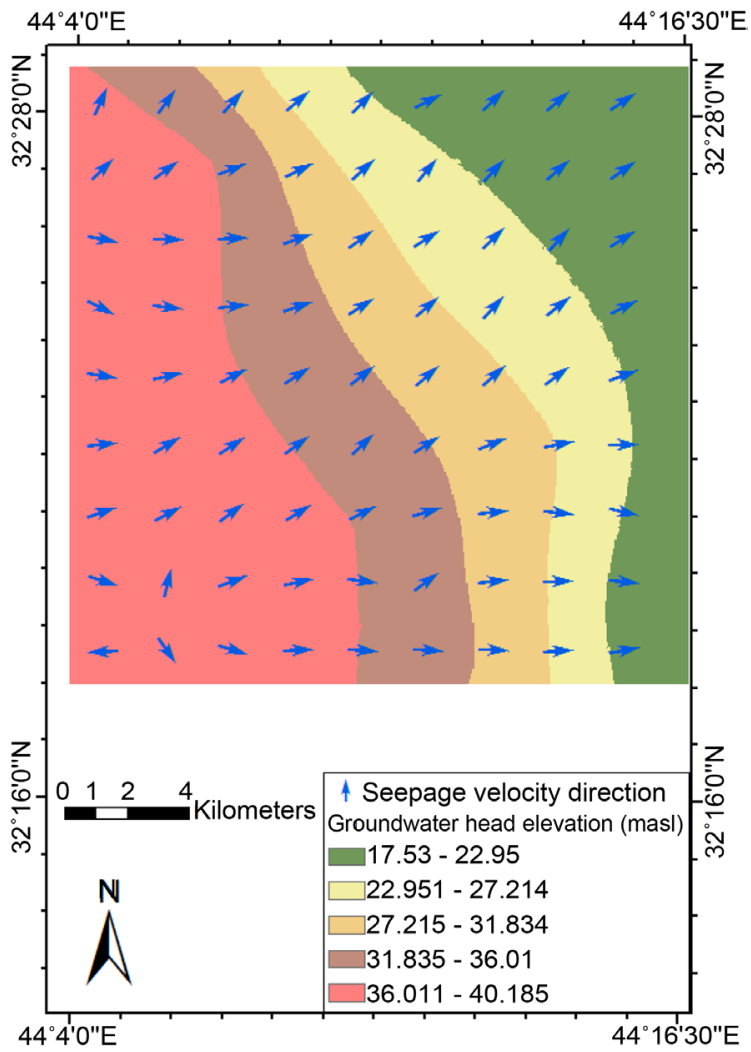

Figure 9. Seepage velocity direction and the groundwater head elevation map.

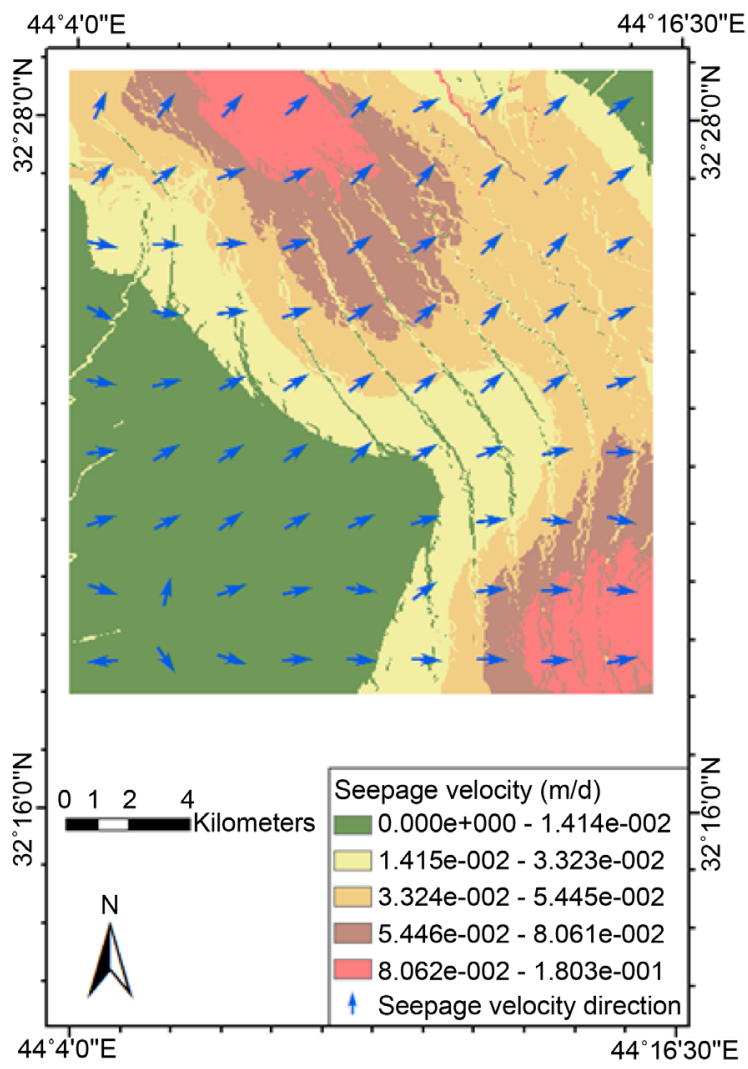

Figure 10. Seepage velocity maps (magnitude and direction). 


\section{Conclusion}

Surface water is the main fresh water resource in Iraq. During the last years Iraq surface water was decreased dramatically. To solve or minimize the consequences of this shortage, other resources that can fulfill the municipality and agriculture requirements are to be used. One of the most important cities in the middle of Iraq is Karbala, due to its religious importance and population which exceeds one million. This city mainly depends on groundwater resources. The results indicated that the groundwater flows from the west to the east toward Mesopotamia Plain. This is due to the fact that Injana formation, which represents the bed of the unconfined Dibdibba aquifer, is dipping in that direction, and the water table is dipping in that direction also. The seepage velocity ranged from $0 \mathrm{~m} / \mathrm{d}$ to $0.18 \mathrm{~m} / \mathrm{d}$. This variation in the seepage velocity is due to the changes in the geo-hydrological properties which govern the seepage velocity (i.e., groundwater elevation head, effective porosity, effective thickness, and transmissivity).

\section{References}

[1] Daniel, B. and Bitzer, B. (2011) Water Desalination with Evaporation from Environmental Friendly Waste Heat Source. 46 th International Universities' Power Engineering Conference, Soest, 5.

[2] Dhakras, P.A. (2011) Nanotechnology Applications in Water Purification and Waste Water Treatment: A Review. International Conference on Nanoscience, Engineering and Technology, Tamilnadu, 285-291. https://doi.org/10.1109/ICONSET.2011.6167965

[3] Al-Ansari, N.A. (2016) Hydropolitics of the Tigris and Euphrates Basins. Engineering, 8, 140-172.

[4] Al-Ansari, N.A. (2013) Management of Water Resources in Iraq: Perspectives and Prognoses. Journal of Engineering, 5, 667-684. https://doi.org/10.4236/eng.2013.58080

[5] Postel, S. (1992) Last Oasis-Facing Water Scarcity. World Watch Institute WW Norton \& Corporation, New York.

[6] Issa, I.E., Al-Ansari, N.A., Sherwany, G. and Knutsson, S. (2014) Expected Future of Water Resources within Tigris-Euphrates Rivers Basin in Iraq. Journal of Water Resource and Protection, 6, 421-432. https://doi.org/10.4236/jwarp.2014.65042

[7] Al-Ansari, N.A., Ali, A. and Knutsson, S. (2014) Present Conditions and Future Challenges of Water Resources Problems in Iraq. Journal of Water Resources and Protection, 6, 1066-1098. https://doi.org/10.4236/jwarp.2014.612102

[8] Al-Ansari, N.A., Ali, A.A. and Knutsson, S. (2015) Iraq Water Resources Planning: Perspectives and Prognoses. XIII International Conference on Civil and Construction Engineering, Jeddah, 26-27.

[9] Obaid, H.A., Shahid, S., Basim, K.N. and Shreeshivadasan, C. (2014) Modeling Sewerage Overflow in an Urban Residential Area Using Strom Water Management Model. Malaysian Journal of Civil Engineering, 26, 163-171.

[10] Al-Ani, A.A.R. (2004) Selection of Best Technique to Evaluate Groundwater Recharge: A Case Study of Dibdibba Aquifer in Area of Karballa-Najaf, PhD Thesis, University of Baghdad, Baghdad. 
[11] Yacoub, S.Y. (2011) Stratigraphy of The Mesopotamia Plain. Iraqi Bull. Geology Special Issues, 4, 47-82.

[12] Hassan, K.M. (2007) Stratigraphy of Karbala-Najaf Area, Central Iraq. Iraqi Bulletin of Geology and Mining, 3, 53-62.

[13] Barwary, A.M. and Slewa, N.A. (1995) Geological Map of Karbala Quadrangle. State Establishment of Geological Survey and Mining, Library, Baghdad.

[14] Al-Mussawi, W.H. (2008) Kriging of Groundwater Level-A Case Study of Dibdiba Aquifer in Area of Karballa-Najaf. Journal of Kerbala University, 6, 170-182.

[15] Ibrahim, S.A.R. and Al-Shammaa, A.M. (2012) Hydrochemistry of Shallow Groundwater in Western Karbala City Central Part of Iraq. Iraqi Bulletin of Geology and Mining, 8, 91-107.

[16] Al-Saadi, R.J.M. (2013) Contour Maps and Evaluation of Groundwater Quality in Karbala Region. Journal of Kerbala University, 11, 204-222.

[17] US Salinity Laboratory (1954) Diagnosis and improvement of saline and alkaline soils. US Department of Agriculture Handbook, 60, 160 p.

[18] Wilcox L.V. (1955) Classification and Use of Irrigation Waters. American Journal of Science, 8, 123-128.

[19] Ramadhan, A., Aljabbari, M. and Alkubaisi, R. (2013) Evaluation of Recharging Arid and Semi-Arid Regions (Case Study of Dibdibba Formation, Karbala PlateuNajaf). Iraqi Journal of Science, 54, 902-910.

[20] Khalaf, A.G. (2016) Location of Best Site for Irrigation Wells Using GIS. Journal of Engineering and Technology, 34, 80-89.

[21] Thabit, J.M. and Khalid, F.H. (2016) Resistivity Imaging Survey to Delineate Subsurface Seepage of Hydrocarbon Contaminated Water at Karbala Governorate. Environmental Earth Sciences, 75-87.

[22] Todd, D.K. and May, L.W. (2005) Groundwater Hydrology. John Wiley \& Sons, Hoboken.

[23] Environmental Systems Research Institute (2017) How Darcy Flow and Darcy Velocity Work.

http://desktop.arcgis.com/en/arcmap/10.3/tools/spatial-analyst-toolbox/how-darcyflow-and-darcy-velocity-work.htm

\section{Submit or recommend next manuscript to SCIRP and we will provide best service for you:}

Accepting pre-submission inquiries through Email, Facebook, LinkedIn, Twitter, etc. A wide selection of journals (inclusive of 9 subjects, more than 200 journals)

Providing 24-hour high-quality service

User-friendly online submission system

Fair and swift peer-review system

Efficient typesetting and proofreading procedure

Display of the result of downloads and visits, as well as the number of cited articles

Maximum dissemination of your research work

Submit your manuscript at: http://papersubmission.scirp.org/

Or contact eng@scirp.org 